\title{
Kenyan Shiite Community: A Socio-Historical Perspective
}

\author{
Dr. Mohamed Sheikh Alio ${ }^{1}$ \\ ${ }^{I}$ Department of Humanities, School of Social Sciences, Mount Kenya University, Kenya.
}

\begin{abstract}
The shiite Muslim community in Kenya is an active religious minority which need to be studied due to their significant role in different aspects of social life in Kenya since the 19th century. The research reveals the original meaning of the word "Shii'ah" or "Shiism" and how it developed later to became a broad title for Shia Islam which represents one of the main Muslim sects in the world. It outlines the early arrivals of Shiite community in Kenya and East Africa during the 19th century. In addition, the paper, also, examines extensive information about their existing cults in Kenya and their social, educational and developmental activities in the country. The article concludes with focusing on some leading Shiite institutions which contribute to the development process in Kenya such as Aga Khan Development Network (AKDN), Bilal Muslim Mission, Burhani Foundation, Rasul al-Akram Academy and Jaffery Academy among others.
\end{abstract}

Key words: Bohora, Ismailis, Ithnaasharis, Shia, Sunni.

\section{Introduction}

The word "Shiite" or "Shiism" is driven from the Arabic word "Shii'ah" which means the supporters, lovers, adherents, followers or defenders of a certain person (Ibnu Manzur, 2009: Vol. 8: 188). The term is shortened from the historical title "Shii'at-Ali," means "The Party of Ali" which was named after the supporters of the fourth caliph in Islam, Ali (600-661 CE), during his battles with his opponents in Arabia between 656 and $661 \mathrm{CE}$.

According to the general perspective of Muslim historians, the name did not exist technically in early days of Islam due to the fact that there were no denominations among Muslim community in those days though Shia scholars disagree with this view; saying that Prophet Muhammad is the one who laid down the foundation of Shiism; by appointing his cousin-in-law, Ali Ibnu Abi Talib, as his legal religious successor at a place near Mecca, called: Ghadiir Khum, in his way to medina, after completing his farewell pilgrimage in 632 CE (AalKashiful-Ghitaa, 1990:118-125).

Politically, the name emerged after the death of third caliph, Uthman Ibnu Affan (577-656 CE); Where his successor, Ali Ibnu Abi Talib, faced rebellion from some of Prophet Muhammad's companions who stipulated - to be loyal to him - to arrest and punish those who killed the third caliph, Uthman Ibnu Affan. At this stage, the supporters of the fourth caliph, Ali Ibnu Abi Talib, were named by others or called themselves Shii'ah because they were supporters and followers of Ali Ibnu Abi Talib in his fighting against his opponent, the governor of Damascus at that time, Mu'awiyah Ibnu Abi Sufyan (Ibnu Hazm, 2007:Vol. 2:8).

Shia Muslims believe that just as the prophet is appointed by God alone, only God has the prerogative to appoint the successor to his prophet. They believe God chose Ali to be Prophet Muhammad's infallible successor as the first Imam (Religious Leader) of Islam. They argue that Prophet Muhammad designated Ali as his successor before his death, as every Imam should designate his successor before his demise.

They state the belief that the Islamic leadership [Imamate] should have stayed within the Prophet's own family, among those specifically appointed by him, or among Imams appointed by God Himself, adding that the Imam is sinless by nature, and that his authority is infallible as it comes directly from God (Al-Shahrastani, 2007:Vol.1:171). As a result, Shia Muslims often venerate their Imams as saints and perform pilgrimages to their tombs and shrines in quest for divine intercession; as they do to Karbala, Al-Najaf (Iraq), Medina (Saudi Arabia), Cairo, Damascus, Mashhad and Qum (Iran). Throughout history, Shia Muslims have not recognized the authority of elected Muslim leaders, choosing instead to follow a line of Imams which they believe have been appointed by the Prophet Muhammad or God Himself.

On the other hand, Sunni Muslims agree with the position taken by the majority of the Prophet's companions, that the new leader should be elected from among those capable of the leadership. This is what was done, and Prophet Muhammad's close companion and advisor, Abu Bakr al-Siddiq, became the first Caliph of the Islamic state. They counter that there is no basis in Islam for a hereditary privileged class of spiritual leaders, and certainly no basis for the veneration or intercession of saints since it contradicts with principles of Islam which based on absolute monotheism.

Sunni Muslims contend that religious and political leadership is not a birthright, but a trust that is earned and which may be given or taken away by the people themselves in accordance with guidelines of 
Islamic law which applies consultation "Shura" as mechanism to elect leaders. The word "Sunni" came from the Arabic word "Sunnah" which means "the road"; and technically means those who followed the traditions of Prophet Muhammad. Sunni Muslims make up the overwhelming majority of world's Muslims; between 87\% and 90\%. Significant populations of Shia Muslims are found in Iran, Iraq, Bahrain and Azerbaijan, with minority communities in Lebanon, Syria, Yemen, Saudi Arabia, UAE, Oman, Pakistan, India, Afghanistan, Kenya, East Africa and the rest of the world (Connie R. Green, Sandra Brenneman Oldendorf, 2010:156).

Coming to this specific paper, the nature of the problem is lack of study which focuses on sociohistorical perspectives of Kenyan Shiite Muslim community which has major contributions to the social developments in Kenya since the 19th century.

The purpose of the research is to cast light on some of Kenyan societies that originate to Asia which help to understanding the post-colonial history of Kenya. No previous work -according to my knowledge - has touched the socio-historical perspective of Kenyan Shiite community though there are some literatures that written on the presence and the activities of Shiite community in Kenya as it clear from No. 7 \& 8 in my list of references.

The contribution of this paper comes from the concrete information offered on the above mentioned topic which can be very useful information for the world's library in social sciences.

\section{Historical Background}

Sunni Islam dominated East African region for long time because those who came to preach Islam along East Africa's coastal lines were Sunnis from Yemen, Iraq, Oman, Somalia and Southern parts in Arabian Peninsula.

The Sunnis were the followers of Imam Shafi'i's school of Islamic jurisprudence (Figh); which is one of the four Sunni schools of thought across Muslim world (Ibnu Batuta, 1987:257).

The first recorded Shiite presence in Kenya was about 1867 during British colony; when some Asian businessmen known as Khoja from the Shiite Ithnaashari (The Twelvers) sect came from India and Zanzibar and settled in Mombasa and Lamu. Most of the arrivals came from Kutch or Kathiawad cities in India but some also came from older Khoja settlements along the East African coast like Bagamoyo, Zanzibar and Kilwa. They were organized in groups and each group has its executive council which has no much powers except organizing the daily life of group, while each group was adherent to its Shiite spiritual leader in Iraq or Iran (Bhalloo, 2009:34).

As time passes, they acquired assets and managed several business activities like steel, Iron works and most of shipping companies were belong to them during 1960s. In addition, they built private schools and hospitals for themselves but later on they opened their service institutions to other races and religions.

Their schools and hospitals were considered among the best institutions in colonial Kenya such as Jaffery Academy. Besides that, they were celebrating their Shiite ceremonies and festivals where their religious congregations were roaming along Nairobi and Mombasa streets to mark the death of their third Imam, Husayn Ibnu Ali, who was killed in Karbala (Iraq) on 13th October, 680 CE (Bute, 2013:54).

Parallel to Shiite Khoja sect, there was another Shiite group arrived in Kenya from Asia with British colony. They are the Ismailis which are sub-divided into Dawoodi Bohora and Aga Khans denominations. The Dawoodi Bohoras arrived in East Africa in the 19th century, primarily to Zanzibar and Lamu. They initially came as traders, but later branching into hardware and glass, and then into real estate and construction activities.

\section{Shiite sects in Kenya}

The Kenyan Shiite community which basically originated from Asia is composed of two main Shiite sects: The twelvers (Ithna-asharis) and the Ismailis (Aga khans and Bohora) as follow:

\subsection{The Twelvers (Ithna-asharis)}

The Twelvers (Ithnaasharis) are the major Shiite sect in the Muslim world. They have been given this name in accordance with their belief in 12 Imams from the family of Prophet Muhammad. They say that all of them have been appointed by God to be the Imams (leaders) of Muslim nations after the death of Prophet Muhammad until the Day of Judgment (Mughniyeh, 2009:15).

This is the list of their Imams and related information as follow:

1. Ali Ibnu Abi Talib (600-666 CE). According to Shia, he was the rightful successor (Imam) of Prophet Muhammad. However, the Sunnis acknowledge him as the fourth Caliph. He was assassinated in Kufa, Iraq, by a Kharijite (rebel) member, Abd-al-Rahman Ibnu Muljam, who slashed him with a poisoned sword. He is buried at Imam Ali Mosque in Najaf, Iraq.

2. Hassan Ibnu Ali (624-670 CE). He succeeded his father in $666 \mathrm{CE}$ as the caliph in Kufa, and on the basis of peace treaty with Syrian Governor, Mu'awiya Ibnu Abii Sufyan, he conceded power in favour of Mu'awiya. Died in Medina and buried in its Al-Baqii' cemetery. 
3. Hussein Ibnu Ali (626-680 CE). He is the younger brother of the said Hassan. Opposed Ummayad Caliph, Yazid I, and planned to fight against him. As a result, he and some of his family were later killed in the Battle of Karbala by Yazid's forces in $680 \mathrm{CE}$. After this incident, the commemoration of Husayn Ibnu Ali's death has become a central ritual in Shiite identity. His head was cut off and sent to Damascus but the rest of his body buried at Karbala, Iraq.

4. Ali Ibnu al-Hussein (658-712 CE). Succeeded Imamate from his father Hussein. Born, lived in Medina and buried in its Al-Baqii' cemetery, Saudi Arabia.

5. Muhammad Ibnu Ali (677-732 CE). Succeeded Imamate from his father. He was famous legal scholar. Buried in Medina's cemetery, Saudi Arabia.

6. Ja'far Ibnu Muhammad (702-765A CE). Born in Medina and considered by Shias as one of those whom established Shiite Ja'fari jurisprudence and Theology. Died in Medina, Saudi Arabia.

7. Musa Ibnu Ja'far (744-799 CE). Is the seventh Imam for Shiite Twelvers while their fellow Ismailis reject his Imamate and claim that his elder brother, Ismail, was Ja'far's legal successor. Buried in AlKadhimiyyah Shrine in Baghdad, Iraq.

8. Ali Ibnu Musa (865-817 CE). Lived during Abbasid caliphate and made crown prince by the Abbasid Caliph, Al-Ma'mun, but later sacked him following to disapproval by the ruling family. Died in Mashhad, Iran, and buried at Imam Reza shrine in Mashhad, Iran.

9. Muhammad Ibnu Ali (810-835 CE). Shias called him Al-Jawwad because of his generosity. Buried in Baghdad at Al-Kadhimayn Shrine near his grandfather's shrine.

10. Ali Ibnu Muhammad (827-868 CE). Strengthened the network of deputies in the Shia community and sent them instructions, and received in turn financial contributions of the faithful and their religious vows. Died In Samarra, Iraq.

11. Hassan Ibnu Ali Al-Askari (846-874 CE). Lived during the tenure of the Abbasid Caliph, Al-Mu'Tamad, and buried in Al-Askari Mosque in Samarra, Iraq.

12. Muhammad Ibnu Al-Hassan Al-Mahdi (868-still a live according to Shias). Twelvers' Shias state that he is the last Imam in their Imamate's chain; saying that he is their current Imam and the promised Mahdi, a messianic figure who will return before the end of the world. They believe that he is living in occultation since 872 CE (Aal-Kashiful-Ghitaa, 1990:145-152).

Twelvers live as minority in most parts of the world, but form majority in Azerbaijan, Iran, Iraq and Bahrain.

In Kenya, they number originally about 3,000-4,000. Most of them live in Mombasa, Nairobi, Kisumu and some major cities and take their religious instructions from their religious leaders in Iraq or Iran.

At Mombasa, they maintain a charitable institution called "Bilal Muslims". The town also hosts the seat of the Supreme Council of the federation of Khoja Shia Ithna-Asheri Jama'at of Africa representing about 17,000 people (Holway, 1973:298).

Unlike Ismailis, the ithna-ashariya carry out active missionary works not only among non-Muslims but also among Sunnis; seeking to convert them to Shia Islam. This conversion works intensified significantly after Khomeini's Islamic Republic of Iran was established in 1979; where they mounted their propagation activities through media, press, educational institutions, charitable works and direct diplomatic financial support from Iran Embassy in Nairobi and managed to convert some sunni youths from Sunnism to Shiism (Ojede, 2000:17).

\subsection{Ismailis}

The Ismailis are Shiite sect which split from Shiite Twelvers' sect after the death of the sixth Imam, Ja'far al-Baqir, in $765 \mathrm{CE}$, where they declared that the succession should be passed through Imam Ja'far's eldest son, Ismail, which the name "Ismailis" has driven from, while Twelvers recognized his younger brother, Musa Al-Kadhim, as the seventh Imam due to the fact that Ismail had died while his father was a live (AlBaghdadi, 1975:62).

Within this group, there was yet another disputed succession in 1094 CE. After the death of Fatimid caliph, Al-Muntasir, The army leader in Egypt, Badr-al-Din al-Jammali, recognized the late caliph's younger son, Al-Musta'li, as Imam, whilst the easterners in Syria recognized his eldest son, Nizar. The followers of Nizar have continued to the present time with yet another disputed succession in $1310 \mathrm{CE}$ producing a small sect in Syria called Nizariyyah (Al-Maqrizi, 1998:Vol. 2:34-35).

The Shiite Ismaili sects in Kenya are further divided into two other small sects as follow:

\subsubsection{Aga Khans}

The Aga Khans are a group of Shiite Ismaili sect which belongs to Nizariyah Shiite Ismaili sect. they are the followers of The Aga Khan, who is originally from Pakistan but resides in London and Paris and visits Kenya and East Africa occasionally. They are about 10,000 of them in Kenya and to them, His Highness, Karim Aga Khan, is the 49th Imam in this line. His followers are known as in East Africa as Ismailis or Khoja. According to the Aga Khan's directives, Ismailis are supposed to adapt to whatever country they live; thus why 
they profess total loyalty to the existing regime wherever they are and stay away from political matters (Ojede, 2000:16).

Ismails in Kenya are organized under three provincial councils at Nairobi, Mombasa and Kisumu. In addition, there is supreme council for Kenya, and the executive and supreme councils for Africa, all with offices in Nairobi. The community has large business activities in Kenya with modern hospitals in Nairobi and Mombasa open to all communities. Education is organized under the provincial councils with a number of nursery, primary and secondary schools in major cities as well as The Aga Khan University Hospital in Nairobi (Holway, 1973:298).

Aga Khan manages several media, press, finance, tourism and service institutions such as: NTV, Daily Nation, Jubilee Insurance Company, Diamond Trust Bank - Kenya [DTB], Serena hotels and resorts.

\subsubsection{Bohora}

Bohora belongs to Musta'liyah Ismaili Shiite sect which recognizes the son of Fatimid caliph, AlMusta'li, as the legal successor to his father, Al-Muntasir, in 1094 CE, contrary to Nizariyah Ismaili Shiite sect which Aga Khan belongs to- that recognizes Nizar as legal successor to Al-Muntasir in 1094. The followers of Al-Musta'li followed his succession down to the 21st Imam al-Tayyib, who as an infant was - as they say "taken into concealment".

The Bohoras believe that their Imams, successors to Al-Tayyib, are living in total secrecy somewhere, and will reveal themselves on some future occasions. In the meantime, the community is ruled by lines of deputies called Dai al-Mutlaq (The absolute preacher).

The current deputy is in the 53rd Dai al-Mutlaq, His Holiness, Mufaddal Saifuddin. He succeeded his father, the 52nd Deputy, Dr. Muhammad Burhanuddin Saheb, who died in Bombay, India, on 17th January, 2014. Dr. Saheb did many occasional visits to Kenya for the interests of his community (Jali, 1986:228).

Disputes in the succession of Dais have caused many schisms among Bohora community. One of these disputes in $1588 \mathrm{CE}$ has divided the community into two sects as follow:

\subsubsection{Dawoodi Bohora}

They are exclusively from India and led by their spiritual leader who resides in India, His Holiness, Mufaddal Saifuddin, who inherited the imamate from his deceased father, Dr. Muhammad Burhanuddin Saheb. All Bohoras in Kenya and East Africa are Dawoodi Bohoras with a number about 7,000 - 8000 member and divided into different sub-groups. They engage primarily in trade and crafts and set up a number of primary and secondary schools which are financed by their Burhani foundation.

One of their most important leaders was Alibhai Mulla Jevanjee, who came to Kenya from Gujrat, India, late in the 19th century and founded a business empire dealing primarily in metal and glass - the chief business interests of the Bohora to this day. In 1905, Jevanjee was appointed by British government as the first non-white member to represent the interests of the Indians in the Legislative Council (Legco) which was established by British administration the same year (Ojede, 2000:16).

\subsubsection{Sulaymaniya Bohora}

They reside in Yemen and South of Saudi Arabia and their current spiritual leader is Sheikh Hassan alMuzamini who lives in Najran, Southern of Saudi Arabia. The members of this sect who are in Saudi Arabia and Yemen are mainly from Bani Yam tribes that have significant population in both Saudi Arabia and Republic of Yemen (Jali, 1986:229).

\section{Shiite leading development and educational institutions in Kenya:}

The leading Shiite developmental organizations are the following:

\subsection{Aga Khan Development Network (AKDN).}

The Aga Khan Development Network (AKDN) is a group of private, non-denominational development agencies which founded and guided by Prince Karim Aga Khan IV. The group seeks to empower communities and individuals to improve living conditions and opportunities, in sub-Saharan Africa, Central and South Asia and the Middle East. The Network focuses on health, education, culture, rural development, institution-building, promotion of economic development and dedicated to improving living conditions and opportunities for the poor without regard to their faith, origin or gender. Its annual budget for not-for-profit endeavours exceeds US\$500 million. The AKDN works in 30 countries around the world, and employs over 80 thousand paid staff, mostly in developing countries.

Among AKDN's agents is The Aga Khan Foundation (AKF) which is a private, not-for-profit international development agency, which was founded in 1967 by the Aga Khan. Similar to AKDN, AKF 
specializes in providing long-term solutions to problems of poverty, hunger, illiteracy and diseases in the poorest parts of South and Central Asia, Eastern and Western Africa and the Middle East.

In these regions, the needs of rural communities in mountainous, coastal and other resource-poor areas are given particular attention. The Foundation's activities often reinforce the work of other sister agencies within AKDN. While these agencies are guided by different mandates pertaining to their respective fields of expertise: environment, culture, microfinance, health, education, architecture and rural development, their activities are often coordinated with one another in order to "multiply" the overall effect that the network has in any given place or community. AKF also collaborates with local, national and international partners in order to bring about sustainable improvements of life in the 19 countries in which it works. The Foundation's head office is located in Geneva, Switzerland.

AKF provides a limited number of scholarships each year for postgraduate studies to outstanding students from developing countries that have no other means of financing their studies. Scholarships are awarded on a 50\% grant: $50 \%$ loan basis through a competitive application process once a year in June or July. The Foundation gives priority to requests for Master's level courses but is also has plans to consider applications for $\mathrm{PhD}$ programmes, when doctoral degrees are necessary for the career objectives of the student. Requests are also considered for travel and study awards for PhD students doing their research in Third World countries on topics judged to be of interest to the Aga Khan Development Network.

Many AKDN's institutions began as voluntary organizations but grew into strong institutions that opened their doors to all East Africans and went on to make important contributions to the development of the nation.

In Kenya, AKF had been active in since 1974, working in health, education, rural development, civil society enhancement and the environment. In 1996, the foundation's branches in Kenya, Tanzania and Uganda merged under a common regional management and governance structure (Ojede, 2000:16).

The Aga Khan Fund for Economic Development (AKFED) has also made key investments in Kenyan industry and infrastructure, including electricity generation, agriculture, media and tourism. AKFED, which has made bold but calculated investments in economic projects ranging from power generation to agri-businesses, operates some of Africa's most successful companies, including many listed on the Nairobi Stock Exchange besides providing employment to tens of thousands of Kenyans.

The Aga Khan University (AKU) has made huge expansions in its activities in health care and professional education of doctors, nurses and teachers. Aga Khan Education Services (AKES) provided 10,000 children with education. Aga Khan Hospital (AKH) serves over 460,000 patients every year in medical institutions throughout the region. The Aga Khan Academy in Mombasa is the first of an international network of schools dedicated to excellence in education.

\subsection{Bilal Muslim Mission - Kenya}

Bilal Muslim Mission - Kenya is religious Shiite charitable organization which works through development and service activities to raise the standard of living of the less fortunate people in rural areas of Kenya. The activities of the mission consist of sponsoring poor students in educational levels, running economic empowerment projects, health action camps, drought response programmes, development works besides conducting Shiite religious celebrations.

The foundation was established in 1964 when the federation of Khoja Shia Ithna Asheri Jamaats of Africa held its conference in December 1964, in Tanga, Tanzania, and passed a unanimous resolution undertaking to convey shiite Islamic teachings to the indigenous Africans in East Africa.

Shiite efforts to spread Shiism among indigenous Africans had been made long before that resolution. Those efforts, however, were by individuals on their own and not made in unison and organised manner. The resolution gave them an impetus to form organizations under the name of Bilal Muslim Mission which was established in both Tanzania and Kenya in honour of the companion Bilal, who was the first Muezzin of Islam. Later, Bilal Muslim Mission of Kenya registered as a religious charity organization on 11th November, 1971.

Bilal Muslim Mission organizes annual Muharram Majlis at their headquarters. The majlis is dedicated to the preservation and perpetuation of the memory of the 'martyrs of Karbala'. A series of lectures is organised to coincide with the mourning period, in which aspects of Shia political history is narrated by the speakers. Not all the guest speakers nor the audience are Shias. A number of Sunni scholars have also been invited to give the public lectures. The lectures are video-taped and disseminated for viewing by a much wider audience, and through this strategy, Shia history and political concerns are made more accessible to non-Shias. This has the double advantage of educating non-Shias about Shiism and on the basis of this, eventually minimising anti-Shia sentiments within the country (Bakari, 1985:66).

Bilal Muslim Mission operates in several areas and run many centres in Southern and western of Kenyan coastal province such as: Mtongwe, Burani, Moyeni, Bahakanda, Miamba, Kichakamkwaju, Shimoni, 
Samburu, Chengoni, Mackinon Road, Demwa and Mwasafu in addition to villages in Eastern Province like: Nzavoni, Kilungu and Masongaleni.

In addition to its supervision on the said centres, the mission offers scholarships for distinguished needy students and holds periodical seminars and workshops for Islamic Religious Education (IRE) teachers, Imams and youth groups in order to preach Shia Islam among them (Bute, 2013:67-77).

\subsection{Burhani Foundation}

Burhani Foundation is a charitable foundation based in India which is founded by former world spiritual leader of Shiite Dawoodi Bohora sect, Dr. Muhammad Burhanuddin Saheb, to promote environmental awareness, research and other developmental activities.

The philosophy which motivates and guides the foundation is based on the core message that the bounties of nature from the Almighty God are entrusted to man to enrich his life and these bounties are protected by the environment of the earth and the sky through which filter down the light and energy of the sun and the beauty and grace of the moon and the stars.

Similar to its works in India, Burhani foundation has established several development projects in Kenya for a long time where the second president of The Republic of Kenya, Daniel Troitich Arap Moi [19782002], was the patron of the foundation in 1980s. Some of 5.2 shillings of the foundation were earmarked for establishment of schools, clinics and various charitable works, although most of those who benefited from the foundation's activities were Dawoodi Bohora sect's members (Ojede, 2000:18).

\subsection{Rasul al-Akram Academy}

Rasul Al Akram Academy is a boys' day and boarding school, offering an integrated curriculum that combines the Kenyan 8.4.4. System of education and Islamic Religious Sciences.

The school is located along Kuwinda Road off Langata Road in Nairobi, Kenya. It sits on a five acre piece of land and consists of the following facilities: Administrative block, tuition block, two science laboratories, a computer laboratory, hostel blocks, multi-purpose hall, library, kitchen, wood workshop, playgrounds, school farm and a Mosque.

Rasul Al Akram Academy was re-opened in 2004 as a non-profit making school, with the objective of providing the much needed education to students from low income families, while at the same time cultivating moral and religious values in them, targeting specifically the unprivileged Muslim community. The school is run by the trustees of the Muntazir Charitable Trust, an Islamic Charitable organization which are sponsored by Iranians.

Apart from what is taught in class, the academy has a programme of religious activities through which it cultivates the spiritual and moral values of the students. They include lectures, Recitation of supplications and acts of worship to mark important events on the Islamic calendar according to Shiite Ithna-Ashari sect's rituals and celebrations. The school employs a total of 18 teachers comprising of graduate and diploma holders with a vast teaching experience. Four of these teach the Islamic Sciences while the rest teach the secular subjects. Among the teachers, they have departmental heads for Mathematics, Sciences, Languages, Humanities, Technical subjects and Shiite Studies (Bute, 2013:78).

\subsection{Jafferi Academy}

Jaffery Academy is a Shiite academy which was founded in 1954 and run by Shiite Khoja Ithnaashari's community in Mombasa. The school offers nursery to Secondary education levels for all communities in addition to an institute which provides different kinds of workshops and short vocational programmes. The Academy has a similar branch in Nairobi known as "Nairobi Jaffery Academy" which is a private coeducational school that endeavours to provide excellence in education designed to meet the needs of individual students within a stimulating learning environment. The Academy aims at educaing students from 2 to 18 years old, from their first steps in schooling through to A-Level. The curriculum of the branch is based on the British National Curriculum but takes into account the wealth of educational resources provided in Kenya, Africa and beyond (Bute, 2013: 65).

\subsection{Amirul Mu'minin Centre}

The centre is located at Matuga, Kwale; near Mombasa and was started in 1992 as Shiite centre which run by Imam Mahdi Foundation. It consists of three educational levels that focus on Ithna-Ashris Shiite studies as follow:

I. Primary Level: Where the student learns the basic studies for Shia Islam in three months. The level targets those completed their secondary certificates before they advance to colleges and University.

II. Preparatory Level: It lasts for two years. In this level, the student learns Sharia and religious studies according to Shiite interpretation. 
III. Secondary Level: It lasts for four years where the student learns Shiite Studies in depth so that he/she can teach or preach Shiite Islam among communities.

The centre has graduated more than 50 students and has managed to secure scholarships for 12 students for further Shiite studies in Syria, Lebanon and other Arab countries.

The first director of the centre was Sheikh Abdallah Nasir and run it from 1992 until 1994. He succeeded by the current director, Hassan Ali Mwaloba. Both Abdallah Nasir and Mwaloba have embraced Shia Islam after being Sunnis as the communities at Kenyan coastal areas (Bute, 2013:65-66).

\subsection{Al-Safa Centre}

The centre is situated at Lamu and was opened in 1969 as Sunni religious centre which run by Sharif Mzee Mwinyi but turned later to Shiite centre due to decision taken by the said Sharif who reconverted from Sunni Islam to Shiism Islam in response to religious and financial influence by some Shiite foreign preachers and scholars whom settled in Lamu. In 1993, the Sharif changed the existing Sunni curriculum of the centre to Shiite curriculum where the centre became a Shiite academy that teaches religious studies according to Shiite sect. Later on, the centre developed from just a religious centre to a primary integrated school that teaches the normal Kenyan primary curriculum in addition to Arabic and Shiite religious studies. The centre has graduated its first lot of primary students in 2012 and is planning to open a secondary school in the coming years. Financially, the centre is run by Ahlul-Bayt Foundation in Lamu, and has religious educational activities in Matondi, Malindi and collaboration with Imam Zainul-Abidiin Shiite School in Mombasa (Bute, 2013:64-65).

\subsection{Ahlul-Bayt Centre}

The centre is located at Kilifi County near Mombasa in Kenyan coastal area. It combines library that consists of Sunni and Shiite books in addition to administrational offices. It is run by Sheikh Abdallah Nasir, a prominent shia figure, who wrote and translated several books in Eglish and Kiswahil in support for Shiite theology and jurisprudence such as: The Hoy Quran; what Shia say, The Shiite perspective towards Sunnis and Mut'a Ndoa Ya Halali which means: The Leisure marriage is legal (in Kiswahili) (Bute, 2013).

\subsection{Conclusion}

Shia Islam is one of the main streams in Islam since the first century of Islam. The Shiite communities are scattered all over the world with high population in some countries in Middle East. In Kenya, the Shiite community consists of different Shiite sects that emigrated from Asia to East Africa for the purposes of discovering more chances for their business ambitions. Later on, they established their own trade, religious and educational institutions which were expanded afterward to serve all Kenyan regardless to their race or religion. In addition to the above mentioned facts and results, Kenyan shiite community is running several leading developmental and charitable institutions which focus on business investments, economic growth, education, health, aid, training, scholarships and empowering communities such as: Aga Khan Development Network (AKDN), Bilal Muslim Mission - Kenya, Burhani Foundation, Rasul al-Akramm and Jaffery Academies. The article suggests that Shiite community in Kenya can be a role model for the rest of Kenyan societies where an organized small community can play significant developmental and charitable roles through organized efforts and skilled members. Further studies can be made on this topic to discover the Kenyan social fabric's elements and utilize that for mutual understanding and peaceful co-existence among Kenyan ethnicities.

\section{References}

[1]. Ibnu Manzur, Muhammad Ibnu Mukarram, Lisanul-Arab (Daru Sadir, Cairo, 2009)

[2]. Aal Kashiful-Ghitaa, Muhammad, Aslu-Shii'ah wa-usuluha (Darul-Adhwaa, Beirut, 1990).

[3]. Ibnu Hazm, Ahmad, Al-Fisalu fil Milali wal-Ahwai wannihal (Daru Ibnu Hazm, Beirut 2007).

[4]. Al-Shahrastani, Abd-al-Karim, Al-Milalu wa al-Nihal (Darul Kutubul Ilmiyyah, Beirut, 2007).

[5]. Connie R. Green, Sandra Brenneman Oldendorf, Religious Diversity and Children's Literature: Strategies and Resources (Information Age Publishing, 2010).

[6]. Ibnu Batuta, Muhammad, Rihlatu Ibnu Batuta (Cairo, 1987).

[7]. Bhalloo, Zahir, Khoja Shia Ithna-asheris in Lamu and Mombasa,1870-1930 (2008). Retrieved from: http://www.sikhheritage.co.uk/heritage/sikhhert\%20EAfrica/nostalgic\%20EA/other\%20towns/khoja\%201amu\%20mombasa\%201.p df.

[8]. Bute, Omar Abdallah, The activities of the Ithna-Ashariyah Shiah, and their impact on the community of the Kenya coastal areas, (Islamic University, Mbale, 2013).

[9]. Mughniyeh, Muhammad Jawad, Al-Ithnaashariyah Wa-ahlili Bayt (Tehran, 2009).

[10]. Holway, James D. Islam in Kenya and relations with the churches, in Bareet, David (Ed.), Kenya Churches Handbook: The development of Kenyan Christianity, 1498-1973 (Evangel Publishing House, Kisumu, Kenya).

[11]. Ojede, Arye, Islam and politics in Kenya (Lynne Rienner Pub. 2000).

[12]. Al-Baghdadi, Abd-al-Qahir, Al-Farqu Bainal Firaq (Beirut, 1975).

[13]. Al-Maqrizi, Taqiyyuddin, Al-Khutatul-Maqriziyyah (Beirut, 1998).

[14]. Jali, Ahmad Muhammad Dirasat 'anil-firaqi fii tarikhil-Muslimina (Riyadh, 1986).

[15]. Bakari, Muhammad (1985). Asian Muslims in Kenya.Retrieved from:

http://www.kenbilal.org/index.php?option=com_content \&view=article\&id=239\%3Ahistory\&catid=101\%3Aabout-us \&Itemid=107. 